\title{
EVALUATION OF SUBSTRATES AND AMF SPORULATION IN THE PRODUCTION OF SEEDLINGS OF NATIVE FOREST SPECIES ${ }^{1}$
}

\author{
Luciana de Moura Gonzaga ${ }^{2 *}$, Sarah Santos da Silva ${ }^{3}$, Silvane de Almeida Campos ${ }^{4}$, Rodrigo de Paula \\ Ferreira $^{5}$, André Narvaes da Rocha Campos ${ }^{6}$ and Ana Catarina Monteiro Carvalho Mori da Cunha ${ }^{6}$
}

\footnotetext{
${ }^{1}$ Received on 27.04.2014 accepted for publication on 03.12.2015.

${ }^{2}$ Universidade Federal de Lavras, Programa de Pós-Graduação em Engenharia Florestal, Lavras, MG, Brasil. E-mail: $<$ lucianagonzaga11@hotmail.com>.

${ }^{3}$ Instituto Federal de Educação, Ciência e Tecnologia do Sudeste de Minas Gerais, Campus Rio Pomba, Graduanda em Agroecologia, Rio Pomba, MG, Brasil. E-mail: <sarahs2209@hotmail.com>.

${ }^{4}$ Universidade Federal de Viçosa, Programa de Pós-Graduação em Agroecologia, Viçosa, MG, Brasil. E-mail: $<$ silvaneacampos@yahoo.com.br>.

${ }^{5}$ Consorcio de Empregadores Cecilia M. S. Mattos e Outros, Fazenda Braúna, Ervália, MG, Brasil.E-mail:<rodrigo_lenny@yahoo.com.br>. ${ }^{6}$ Instituto Federal de Educação, Ciência e Tecnologia do Sudeste de MG, Campus Rio Pomba, Departamento Acadêmico de Agricultura eAmbiente, Rio Pomba, MG - Brasil.E-mail:<andre.campos@ifsudestemg.edu.br>and <catarina.mori@ifsudestemg.edu.br>. ${ }^{*}$ Corresponding author.
}

\begin{abstract}
The objective of this study was to evaluate organic substrates in the production of canafistula (Peltophorum dubium) (Spreng.) Taub, cutieira (Joannesia princeps Vell.), jatoba (Hymenaea courbaril L.) and rubber tree (Hevea brasiliensis $\mathrm{M}$. Arg.) seedlings, native trees with potential use in forest restoration programs. The design was completely randomized with 10 substrate formulations with 4 repetitions of 3 plants for the four species. The evaluated substrates consisted of soil, bovine manure (BM), poultry manure (PM), chemical fertilizer (CF) and sand, in different proportions. The experiment was concluded at the end of 180 days for canafistula, cutieira and rubber and 210 days for jatoba. At the end of these periods, the root (RDM), shoot (SDM) and total (TDM) the dry matters of the seedlings were determined. Quantification of AMF spores and normalization between samples through SPORES/RDM correction were also performed. The Scott-Knott test at $5 \%$ probability was applied. Regarding biomass production, only canafistula had significant difference among the tested substrates. In relation to sporulation, the highest values were observed in cutieira and rubber tree in substrate containing PM. The substrates composed of 40 or $50 \%$ soil $+20 \%$ sand $+30 \%$ or $40 \mathrm{PM}$ for canafistula; $50 \%$ soil $+20 \%$ sand $+30 \%$ PM for cutieira; and for jatoba and rubber tree $60 \%$ soil $+20 \%$ sand $+20 \%$ PM, enabled the best results in terms of biomass production in seedlings and AMF sporulation.
\end{abstract}

Keywords: Waste use; Arbuscular Mycorrhizal Fungi; Endangered Species.

\section{AVALIAÇÃO DE SUBSTRATOS E ESPORULAÇÃO DE FMAS NA PRODUÇÃO DE MUDAS DE ESPÉCIES FLORESTAIS NATIVAS}

\begin{abstract}
RESUMO - O objetivo do trabalho foi avaliar substratos orgânicos na produção de mudas de canafistula (Peltophorum dubium) (Spreng.) Taub., cutieira (Joannesia princeps Vell.), jatobá (Hymenaea courbaril L.) e seringueira (Hevea brasiliensis M. Arg.), arbóreas nativas com potencial uso em programas de restauração florestal. O delineamento utilizado foi inteiramente ao acaso com 10 formulações de substratos com 4 repetições de 3 plantas para as 4 espécies. Os substratos avaliados consistiram em misturas de solo, esterco bovino (EB), cama aviária de poedeiras (CA), fertilizante químico (FQ) e areia, em diferentes proporções. O experimento foi encerrado ao final de 180 dias para a canafístula, cutieira e seringueira e aos 210 dias para o jatobá. Ao final destes períodos foi determinado o peso da massa seca de raiz (MSR), da parte aérea (MSPA) e total (MST) das mudas. Foi realizada a quantificação de esporos de FMAs e a normalização entre as amostras por meio de correção ESPOROS/MSR. Foi aplicado o teste Scott-Knott a 5\% de probabilidade. Quanto à produção de biomassa, somente a canafístula obteve diferença significativa dentre os substratos testados. Em relação à esporulação, os maiores valores foram observados na cutieira e seringueira em substrato contendo
\end{abstract}


CA. Os substratos compostos por 40 ou $50 \%$ solo $+20 \%$ areia +30 ou $40 \%$ CA para canafístula; $50 \%$ solo $+20 \%$ areia $+30 \%$ CA para a cutieira; e para ojatobá e seringueira, $60 \%$ solo $+20 \%$ areia $+20 \%$ $C A$, possibilitaram os melhores resultados quanto à produção de biomassa nas mudas e esporulação de FMAs.

Palavras-chave: Utilização de resíduos; Fungos Micorrízicos Arbusculares; Espécies ameaçadas de extinção.

\section{INTRODUCTION}

The conservation of biodiversity is one of the greatest challenges of humanity, due to the high level of human disturbance on natural ecosystems. According to Viana and Pinheiro (1998), fragmentation is one of the main consequences of this disturbance. Given this situation, forest fragments of various sizes and shapes, are of fundamental importance to the sustainability of the Atlantic Forest biome (ZAU, 1998), which historically and in the first place has been deforested and, subsequently, other biomes such as the Amazon Forest has also suffered impacts. It is necessary to recover these places, where models that combine species from different ecological classes can be used (MARTINS, 2009). Thus, studies related to the production of native species seedlings are relevant, considering that they are the basis of degraded area recovery programs.

The forest species canafistula (Peltophorum dubium) (Spreng.) Taub. is a deciduous and heliophilic plant of the Caesalpiniaceae family of successional group of pioneers. It has extensive natural distribution from the state of Bahia to Paraná, especially in semideciduous broadleaved forest. The canafístula has several uses, including the ornamentation and landscaping for its beautiful flowering and great shading when isolated. A rustic plant of rapid growth, it is recommended for the composition of mixed reforestation of degraded areas (LORENZI, 2002).

Joannesia princeps Vell., commonly known as cutieira belongs to the Euphorbiaceae family, is a pioneer plant, heliophilic, of the pioneer successional to early secondary group (CARVALHO, 2005). It is a native tree, occurring mainly in the Atlantic Forest Biome (LORENZI, 2002). The cutieira has several uses as its seeds have approximately $37 \%$ of oil, useful for medical and industrial purposes (LORENZI, 2002), and potential for biodiesel production (SANTOS et al. 2009). It is a potential species for degraded area recovery programs (BELTRAME, 2013).

The jatoba (Hymenaea courbaril L.) is a tree species belonging to Caesalpiniaceae family with occurrence from Piaui to the north of Paraná in semideciduous forests. A hermaphrodite, semideciduous, semi-heliophilic plant of the late successional secondary group. It has many products and uses, such as: resin; its fresh fruit pulp is used in human food and animal feed; beekeeping; in folk medicine; besides being used in road, park and plaza afforestation (CARVALHO, 2003). It is a promising species to be used in degraded areas recovery programs (MARTINS, 2009) and is considered a phytoremediator plant (CARVALHO, 2003).

The jatobá and canafistula are endangered species, thus, need attention regarding efficient mechanisms for reproduction (BRASIL, 2003).

The rubber tree (Hevea brasiliensis M. Arg.) is a milky tree belonging to the family Euphorbiaceae, semideciduous, heliophilic, occurring in the Amazon region. According to Gama et al. (2002), the species is climax and tolerant to shading. It has many uses, as its seeds that produce oil, useful in the paint and varnish industry, but the highest value of the species lies in the latex extracted from its trunk and is turned into high quality rubber (LORENZI, 2002). It is further indicated for revegetation of degraded areas and its use is potential for the composition of agroforestry systems (TAVARES et al. 2008).

The planting of seedlings is a technique that, besides ensuring the survival of plants in the field, leads to a greater saving of seeds. The germination process is the most sensitive stage of reproduction and when it occurs in the nursery, requires greater care. Choosing the right substrate is critical because it directly influences germination and seedling development. The substrate may be obtained from a variety of materials or mixtures that comprise several desirable and needed characteristics required for seedling development. According to Konzen (2003) and Silva (2008) animal waste is, to a large extent, present on farms and must be recycled in order to be converted into useful and economic agricultural input with a minimum of environmental damage.

Several studies are being conducted with forest species, evaluating the use of alternative substrates 
formulations both in the production of seedlings in the nursery and the behavior of seedlings at transplanting, and have shown satisfactory results, such as Cunha et al. (2005), Araújo and Sobrinho (2011), Dutra et al. (2013), among others. These studies aim to combine the treatment of waste with the production of quality forest species seedlings, using available materials, reducing costs and contributing to reduce environmental impacts.

It is known that there is a close relationship between biodiversity and ecosystem functioning, so the diversity of soil microorganisms can be a determinant of the diversity of plants living in mutualistic symbiotic associations, such as mycorrhizae (GONÇALVES and DINIZ, 2008). The organic matter in the substrate favors the establishment of arbuscular mycorrhizal fungi (AMF) by stimulating the growth and branching of the fungal hyphae into the soil and the formation of a more favorable soil niche for the development of the fungus (JOHN et al., 1983).

The AMF can enhance the seedling production process, by increasing the water and nutrient absorption capacity to the plant. These microorganisms also act on the aggregation of soil particles, contributing to the reduction of erosion and to the air and water permeability in the rhizosphere (RAMOS and FARIA, 2011).

With so many benefits provided by the AMF, many researches have been developed in several areas. The vast majority of the work evaluates the artificial inoculation of AMF in several species, differing from this study, which assesses the effect of the substrate in the production of seedlings and spores, bringing an innovative character. The demand for native tree seedlings is growing. Thus, research that optimize production to meet the goals of planting are relevant (SCREMIN-DIAS et al. 2006). Therefore, seedlings grown in substrates that provide greater AMF sporulation can have the process cheapened, producing seedlings with better development and resistance to stress factors and, consequently, higher survival rates when transplanted to the field.

Thus, the objective of this study was to evaluate the effect of organic substrates in the production of seedlings of canafistula (Peltophorum dubium (Spreng.) Taub.), cutieira (Joannesia princeps Vell.), jatoba (Hymenaea courbaril L) and rubber tree (Hevea brasiliensis M. Arg.), regarding the production of seedling biomass and the amount of AMF spores.

\section{MATERIALS AND METHODS}

The experiment was conducted in the Horto Florestal (forest garden), in the Laboratory of Plant Propagation and Laboratory of Soil Microbiology, of the Department of Agriculture and Environment of IF Sudeste MG, Campus Rio Pomba. The town of Rio Pomba is located in the Zona da Mata Mineira, micro-region of Uba. It has a tropical climate, with an altitude of $441 \mathrm{~m}$, average temperature of $18^{\circ} \mathrm{C}$, and average rainfall of $1,500 \mathrm{~mm}$. According to Cardoso (2001) the relief is strongly undulating, with predominance of deep and well-drained latosol, but acidic and poor in available nutrients.

The canafistula seeds were donated by the Fundação de Pesquisa Agropecuária do Rio Grande do Sul (Agricultural Research Foundation of Rio Grande do Sul) (FEPAGRO), in Santa Maria. It proceeded with the processing of the fruits and seed removal, then the mechanical scarification of seeds for having tegumentary dormancy, rubbing a side of the seed in sandpaper.

The cutieira and rubber tree seeds were collected from parent trees in the Campus Rio Pomba. The cutieira seeds were sown directly in the container and the rubber tree seeds were initially put in seedbed with sand and then transplanted to recipient.

The jatoba seeds were collected in Nepomuceno, Minas Gerais, and the fruits, ripe and on the ground under the trees, were harvested in August. In the processing, the seeds were removed from the fruit and placed in trays with water for 20 minutes to facilitate removal of the floury pulp. The treatment of breaking dormancy proceeded by mechanical scarification, rubbing one side of the seeds on sandpaper.

The design was completely randomized (CRD) with 10 substrate formulations with 4 repetitions of 3 plants each in plastic bags with dimensions of $15 \mathrm{~cm}$ diameter $X 20 \mathrm{~cm}$ height for the four species. The substrates evaluated were formulated from bovine manure (BM) and poultry manure (PM), in different proportions, namely: T1 - pure soil; T2 - soil + fertilizer according to the methodology described in Macedo (1993); T3 - 80\% soil $+20 \%$ sand; $\mathrm{T} 4-80 \%$ soil $+20 \%$ sand + fertilizer; T5 $-60 \%$ soil $+20 \%$ sand $+20 \%$ PM; T6 - 50\% soil $+20 \%$ sand $+30 \%$ PM; T7 $-40 \%$ soil $+20 \%$ sand

Revista Árvore, Viçosa-MG, v.40, n.2, p.245-254, 2016

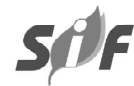


$+40 \%$ PM; T8 $-60 \%$ soil $+20 \%$ sand $+20 \%$ BM; T9 $-50 \%$ soil $+20 \%$ sand $+30 \%$ BM; and $\mathrm{T} 10-40 \%$ soil $+20 \%$ sand $+40 \%$ BM. The bovine manure came from compound of the Horto Florestal of the institution, which receives plant residues from mowing held on campus. The poultry manure was from the poultry sector of the Department of Animal Science of the institution.

The soil used in the experiment is a dystrophic red latosol, typical in the region of Rio Pomba. Samples of soil, sand, bovine and poultry manures were chemically analyzed (Table 1).

The experiment was conducted in a greenhouse for seedlings of canafistula, cutieira and rubber tree and in nursery for jatobá under shadow condition, being irrigated twice a day and hand weeding procedure performed weekly.

At the end of 180 days, the experiment was finished for canafístula, cutieira and rubber tree seedlings. As for the jatobá, it was finished at the end of 210 days. The plants were collected and divided into roots and shoots, washed in distilled water and dried in a forcedair oven at $65^{\circ} \mathrm{C}$ until they reached constant weight. The determination of the root dry mass (RDM) and shoot dry mass (SDM) weights was performed on an analytical balance with $0.01 \mathrm{~g}$ accuracy, and the total dry mass weight (TDM) was obtained by summing RDM and SDM.

For all treatments there were extraction and quantification of AMF spores through rhizospheric soil following the methodology described by Gerdemann and Nicolson (1963). The spores were removed from the samples of $50 \mathrm{~g}$ of soil by wet sieving, followed by centrifugation and floatation in $60 \%$ sucrose. The material obtained was placed in channeled Petri dishes for direct counting of the spores per channel with a stereomicroscope. For purposes of normalization between samples, we performed the correction of the number of spores by the ratio of number of spores with the root dry matter (SPORES/RDM).

The values for each variable analyzed were subjected to analysis of variance and the means were compared by the Scott-Knott test at 5\% probability.

\section{RESULTS}

Among the species, only canafistula had significant differences among the substrates tested (Table 2).

For canafistula seedlings, there was an intense dry matter production showing that it had differentiated growth among the substrates tested (Table 3). As for the cutieira, jatobá and rubber tree, there were no significant effects of the substrates on biomass production. Thus, it is possible to infer that all substrates tested can be employed for these species without differentiation for biomass production. However, regarding the resource utilization aspect available in rural areas, reducing costs in the production process and supply of organic sources in degraded areas, it is appropriate that the seedlings present organic portion in the substrate, since these substrates do not represent reduction of the quality of seedlings.

The canafistula achieved the best results in terms of biomass production in substrates with organic compositions. The T6 and T7 substrates that have the highest proportions of poultry manure (PM) and

Table 1 - Chemical analysis of samples of soil, sand and organic material (poultry and bovine manures) used in the production of seedlings before treatment application. Held in the Laboratório de Análises de Solos Viçosa Ltda (Viçosa Laboratory of Soil Analysis), Viçosa. - MG.

Tabela 1 - Análise química das amostras de solo, areia e materiais orgânicos (cama aviária e esterco bovino) utilizados na produção das mudas antes da aplicação dos tratamentos. Realizadas no Laboratório de Análises de Solos Viçosa Ltda., Viçosa - MG.

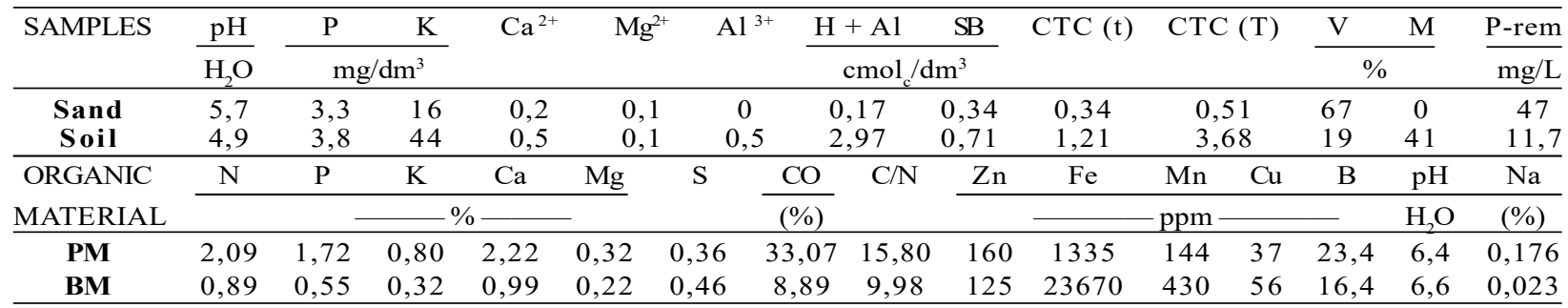

Total contents, determined in the acid extract (nitric acid with perchloric acid), where PM - poultry manure and BM - Bovine manure. 
Table 2 - Shoot (SDM), root (RDM) and total (TDM) dry matter of seedlings of canafistula (Peltophorum dubium) (Spreng.) Taub, cutieira (Joannesia princeps Vell.), rubber tree (Hevea brasiliensis M. Arg.) at the end of 180 days and of jatoba (Hymenaea courbaril L.) at the end of 210 days.

Tabela 2 - Matéria seca da parte aérea (MSPA), de raiz (MSR) e total (MST) de mudas de canafístula (Peltophorum dubium) (Spreng.) Taub., cotieira (Joannesia princeps Vell.), seringueira (Hevea brasiliensis M. Arg.) ao final de 180 dias e jatobá (Hymenaea courbaril L.) ao final de 210 dias.

\begin{tabular}{|c|c|c|c|c|}
\hline \multirow[t]{2}{*}{$\mathrm{FV}$} & \multirow[t]{2}{*}{ DF } & \multicolumn{3}{|c|}{ CANAFISTULA } \\
\hline & & $\operatorname{SDM}(\mathrm{g})$ & RDM (g) & $\mathrm{TDM}(\mathrm{g})$ \\
\hline $\begin{array}{c}\text { Treatments } \\
\text { CV (\%) }\end{array}$ & 9 & $\begin{array}{c}6,51 * * \\
38,94\end{array}$ & $\begin{array}{c}4,52 * * \\
71,74\end{array}$ & $\begin{array}{c}6,36 * * \\
44,64\end{array}$ \\
\hline \multirow[t]{2}{*}{ FV } & DF & \multicolumn{3}{|c|}{ CUTIEIRA } \\
\hline & & $\operatorname{SDM}(g)$ & RDM (g) & TDM $(\mathrm{g})$ \\
\hline $\begin{array}{c}\text { Treatments } \\
\text { CV }(\%)\end{array}$ & 9 & $\begin{array}{c}1,48 \mathrm{~ns} \\
49,86\end{array}$ & $\begin{array}{c}1,19 \mathrm{~ns} \\
35,21\end{array}$ & $\begin{array}{c}1,43 \mathrm{~ns} \\
42,54\end{array}$ \\
\hline \multirow[t]{2}{*}{ FV } & $\mathrm{DF}$ & \multicolumn{3}{|c|}{ JATOBÁ } \\
\hline & & $\operatorname{SDM}(\mathrm{g})$ & RDM (g) & TDM $(\mathrm{g})$ \\
\hline $\begin{array}{c}\text { Treatments } \\
\text { CV (\%) }\end{array}$ & 9 & $\begin{array}{c}0,99 \mathrm{~ns} \\
38,41\end{array}$ & $\begin{array}{c}1,02 \mathrm{~ns} \\
44,83\end{array}$ & $\begin{array}{c}1,04 \mathrm{~ns} \\
38,5\end{array}$ \\
\hline \multirow[t]{2}{*}{ FV } & $\mathrm{DF}$ & \multicolumn{3}{|c|}{ RUBBER TREE } \\
\hline & & $\operatorname{SDM}(g)$ & RDM (g) & TDM $(g)$ \\
\hline $\begin{array}{c}\text { Treatments } \\
\text { CV (\%) }\end{array}$ & 9 & $\begin{array}{c}1,12 \mathrm{~ns} \\
25,27\end{array}$ & $\begin{array}{l}1,8 \mathrm{~ns} \\
23,15\end{array}$ & $\begin{array}{l}1,2 \mathrm{~ns} \\
21,46\end{array}$ \\
\hline
\end{tabular}

** Significant at level of $1 \%$ probability $(\mathrm{p}<.01)$. ns - Non significant $(\mathrm{p}>=.05)$.

F Values obtained.

Table 3 - Shoot (SDM), root (RDM) and total (TDM) dry matter of seedlings of canafistula (Peltophorum dubium) (Spreng.) Taub. at the end of 180 days.

Tabela 3 - Matéria seca da parte aérea (MSPA), de raiz (MSR) e total (MST) de mudas de canafístula (Peltophorum dubium) (Spreng.) Taub. ao final de 180 dias.

\begin{tabular}{|c|c|c|c|}
\hline \multirow[t]{2}{*}{ SUBSTRATES } & \multicolumn{3}{|c|}{ CANAFISTULA } \\
\hline & $\operatorname{SDM}(\mathrm{g})$ & RDM (g) & TDM (g) \\
\hline T1 - So & $1,26 \mathrm{~b}$ & $0,29 \mathrm{~b}$ & $1,55 \mathrm{c}$ \\
\hline $\mathrm{T} 2-\mathrm{So}+\mathrm{CF}$ & $1,30 \mathrm{~b}$ & $0,33 \mathrm{~b}$ & $1,63 \mathrm{c}$ \\
\hline T3: $80 \%$ So: $20 \% \mathrm{Sa}$ & $1,69 \mathrm{~b}$ & $0,55 \mathrm{~b}$ & $2,24 \mathrm{c}$ \\
\hline T4: $80 \%$ So: $20 \% \mathrm{Sa}+\mathrm{CF}$ & $1,50 \mathrm{~b}$ & $0,29 \mathrm{~b}$ & $1,79 \mathrm{c}$ \\
\hline T5: $60 \%$ So: $20 \%$ Sa: $20 \% \mathrm{PM}$ & $2,80 \mathrm{~b}$ & $1,44 \mathrm{a}$ & $4,24 \mathrm{~b}$ \\
\hline T6: $50 \%$ So: $20 \% \mathrm{Sa}: 30 \% \mathrm{PM}$ & $4,82 \mathrm{a}$ & $2,03 \mathrm{a}$ & 6,85 a \\
\hline T7: 40\%So:20\%Sa:40\%PM & 3,43 a & $2,96 \mathrm{a}$ & 6,39 a \\
\hline T8: $60 \%$ So: $20 \% \mathrm{Sa}: 20 \% \mathrm{BM}$ & $2,03 \mathrm{~b}$ & $0,72 \mathrm{~b}$ & $2,76 \mathrm{c}$ \\
\hline T9: $50 \%$ So: $20 \% \mathrm{Sa}: 30 \% \mathrm{BM}$ & $4,45 \mathrm{a}$ & $2,21 \mathrm{a}$ & 6,66 a \\
\hline T10: $40 \%$ So: $20 \%$ Sa:40\%BM & $2,63 \mathrm{~b}$ & $1,57 \mathrm{a}$ & $4,20 \mathrm{~b}$ \\
\hline
\end{tabular}

Columns represented by lowercase letters vertically. Where: So - soil; CF - chemical fertilizer; SA - sand; PM - poultry manure; BM - bovine manure. * Means obtained by the Scott-Knott test at 5\% probability.

T9 with $30 \%$ of bovine manure had the best rates as the production of SDM and TDM. All substrates composed of poultry manure and the largest proportions of bovine manure (T9 and T10) provided higher values for the RDM.

When evaluating the effect of substrates on the production of AMF spores, it is possible to observe that it influences differently on each species (Table 4 and 5). Table 4 shows that there was a significant difference among treatments, substrates and species, and that there was also a significant interaction among them regarding the production of spores (SPORES) and in the relation spores per dry root weight (SPORES/RDM). It is noteworthy that each species was evaluated separately, and among them, there were no comparisons, 
Table 4 - Effect of substrates on the growth of seedlings of canafístula (Peltophorum dubium) (Spreng.) Taub, cutieira (Joannesia princeps Vell.) and rubber tree (Hevea brasiliensis M. Arg.) at the end of 180 days and Jatoba (Hymenaea courbaril L.) at the end of 210 days for the production of spores (SPORES) and the ratio spores per root dry matter (SPORES/RDM).

Tabela 4 - Efeito de substratos no crescimento de mudas de canafistula (Peltophorum dubium) (Spreng.) Taub., cotieira (Joannesia princeps Vell.) e seringueira (Hevea brasiliensis M. Arg.) ao final de 180 dias e jatobá (Hymenaea courbaril L.) ao final de 210 dias quanto à produção de esporos (ESPOROS) e quanto a relação esporos por matéria seca de raiz (ESPOROS/MSR).

\begin{tabular}{lcccc}
\hline FV & DF & SPORES & \\
\cline { 2 - 5 } Substrates (S) & 9 & $19,25 * *$ & SPORES/RDM \\
Species (Sp) & 3 & $11,41 * *$ & $8,8 * *$ \\
S X Sp & 27 & $4,3 * *$ & $25,24 * *$ \\
Treatments & 39 & $8,3 * *$ & $3,32 * *$ \\
CV $(\%)$ & & 46,03 & $6,3 * *$ \\
\hline
\end{tabular}

** Significant at the level of $1 \%$ probability $(\mathrm{p}<.01)$. ns - Not significant $(\mathrm{p}>=.05)$. by Scott-Knott test at $5 \%$ probability.

Table 5 - Effect of substrates on the growth of seedlings of canafistula (Peltophorum dubium) (Spreng.) Taub, cutieira (Joannesia princeps Vell.) and rubber tree (Hevea brasiliensis M. Arg.) at the end of 180 days and of jatoba (Hymenaea courbaril L.) at the end of 210 days as to the production of arbuscular mycorrhizal fungi (AMF) spores and as to the production of arbuscular mycorrhizal fungi per weight of root dry matter (SPORES/RDM).

Tabela 5 - Efeito de substratos na produção de mudas de canafístula (Peltophorum dubium) (Spreng.) Taub., cotieira (Joannesia princeps Vell.) e seringueira (Hevea brasiliensis M. Arg.) ao final de 180 dias e jatobá (Hymenaea courbaril L.) ao final de 210 dias, quanto a produção de esporos de fungos micorrízicos arbusculares (FMAs) e quanto a produção de esporos de fungos micorrízicos arbusculares (FMAs) pelo peso de matéria seca de raiz (ESPOROS/MSR).

\begin{tabular}{|c|c|c|c|c|}
\hline \multirow[t]{2}{*}{ SUBSTRATES } & \multicolumn{4}{|c|}{ SPECIES } \\
\hline & Canafistula & Cutieira & Jatobá & Rubber tree \\
\hline \multicolumn{5}{|c|}{ SPORES } \\
\hline T1 - So & $129,25 \mathrm{~b}$ & $118 \mathrm{~b}$ & $101 \mathrm{c}$ & $118,25 \mathrm{~b}$ \\
\hline $\mathrm{T} 2-\mathrm{So}+\mathrm{CF}$ & $97,25 \mathrm{~b}$ & $94,5 \mathrm{~b}$ & $81,66 \mathrm{c}$ & $131,5 \mathrm{~b}$ \\
\hline T3: $80 \%$ So: $20 \% \mathrm{Sa}$ & $67,75 \mathrm{~b}$ & $459 \mathrm{~b}$ & $89,75 \mathrm{c}$ & $177,25 \mathrm{~b}$ \\
\hline T4: $80 \%$ So: $20 \% \mathrm{Sa}+\mathrm{CF}$ & $49,75 \mathrm{~b}$ & $70 \mathrm{~b}$ & $47 \mathrm{c}$ & $99,25 \mathrm{~b}$ \\
\hline T5: $60 \%$ So: $20 \%$ Sa: $20 \% \mathrm{PM}$ & $107,75 \mathrm{~b}$ & 939 a & $607 \mathrm{a}$ & $3748,25 \mathrm{a}$ \\
\hline T6: $50 \%$ So:20\%Sa:30\%PM & $537,5 \mathrm{a}$ & $1064,25 \mathrm{a}$ & $265 \mathrm{~b}$ & $821,5 \mathrm{~b}$ \\
\hline T7: $40 \%$ So: $20 \%$ Sa:40\%PM & 404,74 a & 893,75 a & $160,25 \mathrm{c}$ & $315,25 \mathrm{~b}$ \\
\hline T8: $60 \%$ So: $20 \%$ Sa:20\%BM & $103 \mathrm{~b}$ & $129,75 \mathrm{~b}$ & $72,25 \mathrm{c}$ & $124,5 \mathrm{~b}$ \\
\hline T9: $50 \%$ So: $20 \%$ Sa:30\%BM & $94 \mathrm{~b}$ & $85,25 \mathrm{~b}$ & $102 \mathrm{c}$ & $108,25 \mathrm{~b}$ \\
\hline T10: 40\%So:20\%Sa:40\%BM & $51,75 \mathrm{~b}$ & $171,75 \mathrm{~b}$ & $173,75 \mathrm{c}$ & $227,75 \mathrm{~b}$ \\
\hline $\mathrm{CV} \%$ & 44,63 & 51,93 & 23,23 & 45,93 \\
\hline \multicolumn{5}{|c|}{ SPORES/RDM } \\
\hline $\mathrm{T} 1-\mathrm{So}$ & 657,22 a & $12,91 \mathrm{~b}$ & $53,94 \mathrm{c}$ & $17,92 \mathrm{c}$ \\
\hline $\mathrm{T} 2-\mathrm{So}+\mathrm{CF}$ & $266,78 \mathrm{a}$ & $8,97 \mathrm{~b}$ & $56,6 \mathrm{c}$ & $17,32 \mathrm{c}$ \\
\hline T3: $80 \%$ So: $20 \% \mathrm{Sa}$ & $111,33 \mathrm{a}$ & 39,2 a & $45,45 \mathrm{c}$ & $21,52 \mathrm{c}$ \\
\hline $\mathrm{T} 4: 80 \% \mathrm{So}: 20 \% \mathrm{Sa}+\mathrm{CF}$ & $317,36 \mathrm{a}$ & $6,11 \mathrm{~b}$ & $32,8 \mathrm{c}$ & $13,84 \mathrm{c}$ \\
\hline T5: $60 \%$ So: $20 \%$ Sa: $20 \% \mathrm{PM}$ & $230,68 \mathrm{a}$ & $44,74 \mathrm{a}$ & 599,73 a & $560,99 \mathrm{a}$ \\
\hline T6: $50 \%$ So: $20 \% \mathrm{Sa}: 30 \% \mathrm{PM}$ & $332,55 \mathrm{a}$ & $86,17 \mathrm{a}$ & $300,52 \mathrm{~b}$ & $167,1 \mathrm{~b}$ \\
\hline T7: $40 \%$ So: $20 \% \mathrm{Sa}: 40 \% \mathrm{PM}$ & $161,42 \mathrm{a}$ & 53,62 a & $228,27 \mathrm{c}$ & $52,6 \mathrm{c}$ \\
\hline T8: $60 \%$ So: $20 \%$ Sa:20\%BM & 149,43 a & $10,2 \mathrm{~b}$ & $42,85 \mathrm{c}$ & $15,54 \mathrm{c}$ \\
\hline T9: $50 \%$ So: $20 \% \mathrm{Sa}: 30 \% \mathrm{BM}$ & $49,71 \mathrm{a}$ & $5,71 \mathrm{~b}$ & $62,25 \mathrm{c}$ & $15,02 \mathrm{c}$ \\
\hline T10: $40 \%$ So: $20 \%$ Sa:40\%BM & 32,58 a & $13,5 \mathrm{~b}$ & $225,56 \mathrm{~b}$ & $28,14 \mathrm{c}$ \\
\hline $\mathrm{CV} \%$ & 55,19 & 48,78 & 41,87 & 51,86 \\
\hline
\end{tabular}

Columns represented by lowercase letters vertically. Where: So - soil; CF - chemical fertilizer; Sa - sand; PM - poultry manure; BM - bovine manure. * Means obtained by the Scott-Knott test at $5 \%$ probability. Letters and variation coefficients obtained by the transformation of data into square root of $\mathrm{x}$. 
given the differences they present, but the effects that the substrates provided for the production of AMF spores (Table 5).

For canafistula, the highest production of spores occurred in substrates containing proportion of poultry manure, namely in the T6 and T7. These treatments represent the best values for this species, both for biomass production in seedlings and for AMF sporulation.

The species showing higher values for the production of AMF spores were rubber tree and cutieira (non-legume species). In the rubber tree, the responsive treatment was $\mathrm{T} 5$ containing poultry manure, which is a much superior substrate compared to the others tested. For cutieira, all substrates that have PM in their composition showed high AMF sporulation. For jatobá, the treatments T5 and T6 with PM in their composition enabled high sporulation. The production of spores for the species was most significant in the organic substrates, specially poultry manure (Table 5).

For purposes of normalization among samples, we performed the correction of the number of spores by the ratio number of spores per root dry matter (SPORES/RDM), a factor that brings the actual value of sporulation (Table 5).

In canafistula, there was no significant difference among the substrates for the variable SPORES/RDM. However, when analyzing the figures, it is possible to see that in $\mathrm{T} 1$ there was a high production of spores, which matches the substrate pure soil. Thus, it can be inferred that the species is great for composing mixed planting for degraded areas recovery. In the result of soil analysis (Table 1), it shows low acidity and clayey texture, aspects that are undesirable for seedlings in general, but that allowed higher AMF sporulation, which may increase the survival rate of the seedlings when transplanted into the field.

The rubber tree and, especially the cutieira, possibly are species that have medium to low percentage of symbiosis formation with AMF, since the production of spores was low for this variable (SPORES/RDM). Only the substrates containing poultry manure achieved the highest results in terms of sporulation for cutieira in the treatment T6 and for rubber tree and jatobá in $\mathrm{T} 5$. With this result, it can be inferred that these substrates are a favorable environment for the production of AMF spores along with the roots of seedlings.

\section{DISCUSSION}

The morphological parameters related to the dry matter production in seedlings should be at maximum values (CARNEIRO, 1995). This variable expresses the capacity by which the seedlings have to use existing resources to produce higher rates of photosynthesis and biomass.

Souza et al. (2012), conducting a nutritional study on canafistula, concluded that the species has a high requirement of the nitrogen from chemical fertilizers. The organic substrates tested in this experiment, especially poultry manure (Table 1 ), are rich in nitrogen and, thus, have supplied the nutritional needs of canafistula. According to Gonçalves (1995), for seedlings of Eucalyptus, Pinus and forest species of the Atlantic Forest, the adequate nutrition with, mainly, chemical fertilizers is relevant. The same author also reported that substrate compositions with organic fertilizer have obtained good results; however, he reported that native species, especially regarding the level of ecological succession, are more nutrient-demanding and, therefore, have a larger permanence time in the nursery.

In the present experiment, species of different stages of ecological succession were evaluated, all of which showed good results in the use of organic substrates for biomass production. Then, the employment of organic material in the substrates enabled desirable physical characteristics and may also have given adequate nutrition to the good development of the plants, especially the canafistula. It is noteworthy that, according to Martins (2012), the main criterion for defining the characteristics of the substrate must be physical, because the chemical aspects are relatively easy to be fixed.

The seeds of cutieira, jatoba and rubber tree have energy reserves in their composition, so the need for rich substrate nutrients to the initial stage of development and establishment of seedlings is less relevant or even insignificant when compared to canafistula, which has no energy reverse in its seeds. Thus, despite the great difference between the composition and proportion of the components of the evaluated substrates, there was no significant difference among them for cutieira, Jatoba and rubber tree in relation to biomass production in plants during the evaluation period of this experiment.

Cunha et al. (2005) recommend underground soil and organic compound for adequate production of purple Ipe (Tabebuia impetiginosa) seedlings. Araujo and

Revista Árvore, Viçosa-MG, v.40, n.2, p.245-254, 2016 
Sobrinho (2011) observed that the weight of the biomass of tamboril seedlings is influenced by the addition of substrates composed of organic material, corroborating the data obtained in this work for the four species studied.

The spore production effect is not only related to the type of substrate, but is also under the influence of the forestry species in which it is inserted. Siqueira et al. (2002) affirmed that the colonization of the roots is inhibited by self-regulatory mechanisms of symbiosis, turning AMF unnecessary and incompatible with the conditions of excess or shortage of nutrients in the soil; so, it is important to assess the nutritional needs of each species.

The organic matter present in the substrate may have enhanced the sporulation for rubber tree and cutieira seedlings, compared to jatobá and canafistula that, because they are leguminous species, have greater potential for association with soil microorganisms. This fact did not provide an increase in biomass production of plants in nursery conditions. Nevertheless, Carneiro (1995) reports various experiments where mycorrhizal plants have better survival and development conditions after planting, and these substrates with poultry manure are promising for both species.

Dutra et al. (2013), when analyzing alternative substrates for the production of canafistula seedlings, obtained the best results with the sugarcane bagasse composing the substrates, from mixing with Bioplant ${ }^{\circledR}$ in the ratio of $3: 1$ (75\% Bioplant $+25 \%$ sugarcane bagasse) and 1:1 (50\% Bioplant $+50 \%$ sugarcane bagasse). Carvalho Filho et al. (2003), in experiment to produce Jatoba (Hymenaea courbaril L.) seedlings at 180 days of age, recommended substrates containing a mixture of soil, sand and bovine manure in the volumetric ratio of $1: 2: 1$. It is similar to the result obtained in this experiment, which allows to infer that seedlings of that species and of canafistula have a good development in substrates containing organic matter.

Siqueira et al. (2002) state that the nutritional effects of AMF depend on the relative availability of elements in the substrate and the requirement of the plant, being more accentuated in deficiency conditions, especially of phosphorus. In addition, among the action mechanisms of these fungi is the biofertilization that bestows greater absorption and utilization of nutrients from the soil. When observing Table 3 and relating it to Table 5 for canafistula, the substrate T1 granted low growth in terms of plant biomass as a whole, but enabled high sporulation, given the improper conditions of the substrate in terms of structure, texture, etc. These conditions stimulated AMF sporulation, possibly because the substrate is a stress factor to the plant, activating self-regulation mechanisms of the AMF, favoring greater absorption and utilization of nutrients from the soil, mitigating nutritional stress and access to not readily available nutrients (SIQUEIRA et al., 2002).

According to Carneiro et al. (1998), the species of the Caesalpiniaceae family (legumes) have no AMF colonization. Probably, the canafistula and jatobá have symbiosis with AMF, being influenced in accordance with the development conditions encountered.

There are many studies evaluating artificial inoculation of AMF in rubber tree. Diniz et al. (2010), when inoculating mycorrhizal fungi Glomus clarumi, observed that there was growth and development for the formation of rubber tree seedlings. Moraes et al. (2010), when assessing the degree of colonization in adult rubber tree plantations, found that there was no significant increase in the development of plants transplanted in relation to mycorrhiza and for the adult plantation, they indicated a low degree of mycorrhizal colonization and number of spores.

The recovery of degraded areas is a very slow process and requires large input of organic matter to the soil structure and, thereby, to improve the local fertility (MODESTO et al. 2009). The use of substrates containing poultry manure is a cheap and accessible alternative for farmers who wish to restore the areas of permanent preservation or even as a support for recovery of degraded areas program, making them more sustainable.

The mycorrhizal fungi spores present in larger proportions in organic substrates can be used to improve soil conditions of degraded areas.

\section{CONCLUSION}

The use of organic substrates allowed suitable morphological parameters in seedlings and high sporulation of arbuscular mycorrhizal fungi. Treatments that allowed the best values were: for canafistula (Peltophorum dubium (Spreng.) Taub. the substrates containing between 40 and $50 \%$ soil $+20 \%$ of sand +30 to $40 \%$ poultry manure; for cutieira (Joannesia princeps Vell.), the substrate containing 50\% soil + $20 \%$ sand $+30 \%$ poultry manure; and for jatoba 
(Hymenaea courbaril L.) and rubber tree (Hevea brasiliensis $\mathrm{M}$. Arg.), $60 \%$ soil $+20 \%$ sand $+20 \%$ poultry manure, which allows reuse of waste present in rural areas, hence, reducing costs and increasing organic matter to the soil when the seedlings are transferred to the field.

\section{ACKNOWLEDGEMENTS}

Seizing the opportunity of the research, I thank the contributors; the IF Sudeste Campus Rio Pomba for their support; my professors André and Catarina for the guidelines and partnerships.

\section{REFERENCES}

ARAÚJO, A.P.; PAIVA SOBRINHO, S. Germinação e produção de mudas de tamboril (Enterolobium contortisiliquum (Vell.) Morong) em diferentes substratos. Revista Árvore, v.35, n.3, Edição especial, p.581-588, 2011.

BELTRAME, R.A. Germinação, morfologia e análise da distribuição espacial da qualidade fisiológica de sementes de Joannesia princeps Vell. 2013. 89f. Dissertação (Mestrado em Ciências Florestais) -

Universidade Federal do Espírito Santo, Alegre, 2013.

BRASIL. Secretaria de Meio Ambiente.

Resolução SMA No 47 de 26 de nov. de 2003. Disponível em: http://

licenciamento.cetesb.sp.gov.br/legislacao/ estadual/resolucoes/2003_Res_SMA_47.pdf Acesso em: 29 jul. 2013.

CARDosO, I.M. Sistemas Agroflorestais na Zona da Mata de Minas Gerais: um processo contínuo de aprendizado. 2001.

Disponível em: http://saf.cnpgc.embrapa.br/ publicacoes/16.pdf. Acesso em: 20 jul. 2013.

CARneiro, J.G.A. Produção e controle de qualidade de mudas florestais. Curitiba: UFPR/FUPEF; Campos: UENF, 1995. 451p.

CARNEIRO, M.A.C.; SIQUEIRO, J.O.; MOREIRA, F.M.S.; CARVALHO, D.; BOTELHO, S.A.; SAGGIN JÚNIOR, O.J. Micorriza arbuscular em espécies arbóreas e arbustivas nativas de ocorrência no sudeste do Brasil. Cerne, v.4, n.1, p.129-145, 1998.
CARVALHO, P.E.R. Boleira (Joannesia princeps Vell.). Circular técnica 105, Colombo, 2005. Disponível em: http://www.cnpf.embrapa.br/publica/ circtec/edicoes/circ-tec 105.pdf Acesso em 04 out. 2013.

CARVALHO FILHO, J.L.S.; ARRIGONI BLANK, M.F.; FITZGERALD BLANK, A.; RANGEL, M.S.A. Produção de mudas de jatobá (Hymenaea courbaril L.) em diferentes ambientes, recipientes e composições de substratos. Cerne, v.9, n.1, p.109-118, 2003.

CARVALHO, P.E. R. Espécies arbóreas brasileiras. Brasília: Embrapa Informação Tecnológica; Colombo: Embrapa Florestas, 2003.v.1. p.601-607.

CUNHA, A.O.; ANDRADE, L.A. BRUNO, R.L.A. SILVA, J.A.L.; SOUZA, V.C. Efeitos de substratos e das dimensões dos recipientes na qualidade das mudas de Tabebuia impetiginosa (Mart. Ex D.C.) Standl. Revista Árvore, v.29, n.4, p.507-516, 2005.

DINIZ, P.F.A.; OLIVEIRA, L.E.M.; GOMES, M.P.; CASTRO, E.M.; MESQUITA, A.C.; BONOME, L.T.S.; SILVA, L. Crescimento, parâmetros biofísicos e aspectos anatômicos de plantas jovens de seringueira inoculadas com fungo micorrízico arbuscular Glomus clarum. Acta Botânica Brasileira, v.24, n.1, p.65-72, 2010.

DUTRA, T.R.; MASSAD, M.D.; SARMENTO, M.F.Q.; OLIVEIRA, J.C. Substratos alternativos e métodos de quebra de dormência para produção de mudas de canafístula. Revista Ceres, v.60, n.1, p.72-78, 2013.

GAMA, J.R.V.; BOTELHO, S.A.; BENTES-GAMA, M.M. Composição florística e estrutural da regeneração natural de florestas secundárias de várzea baixa no estuário amazônico. Revista Árvore, v.26, p.559-566, 2002.

GERDEMANN, J.W.; NICOLSON, T.H. Spores of mycorrhizal Endogone species extracted from soil by wet sieving and decanting. Translation British Mycology Society, v.46, n.2, p.235244, 1963.

GONÇALVES, A.Z.; DINIZ, S. Diversidade de interações micróbio-planta e processos

Revista Árvore, Viçosa-MG, v.40, n.2, p.245-254, 2016

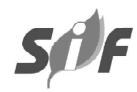


ecossistêmicos. Ecologia de Comunidades e Ecossistemas. Campinas: UNICAMP, 2008. 15p.

GONÇALVES, J.L.M. Recomendações de adubação para Eucalyptus, Pinus e espécies típicas da Mata Atlântica. Piracicaba: 1995. 15p. (Documentos Florestais)

JOHN, T. V. St.; COLEMAN, D. C.; REID, C. P. P. Association of Vesicular-Arbuscular Mycorrhizal Hyphae with Soil Organic Particles. Ecology. v. 64, n. 4, 1983. Disponível em: http://

www.jstor.org/discover/10.2307/ 1937216 ?uid $=2 \&$ uid $=4 \&$ sid $=21103153962973$. Acesso em 26 nov. 2013.

KONZEN, E.A. Fertilização de lavoura e pastagem com dejetos de suínos e cama de aves. Sete Lagoas: Embrapa Milho e Sorgo, 2003. 10p. (Circular Técnica, 31)

LORENZI, H. Árvores Brasileiras: manual de identificação e cultivo de plantas arbóreas do Brasil. 2.ed. São Paulo: Nova Odessa, 2002. v.2. 384 p.

MACEDO, A.C. Produção de mudas em viveiros florestais: espécies nativas. São Paulo: Fundação Florestal, 1993.

MARTINS, S.V. (Ed.) Restauração ecológica de ecossistemas degradados. Viçosa: UFV, 2012.

MARTINS, S.V. Recuperação de áreas degradadas: ações em áreas de preservação permanente, voçorocas, taludes rodoviário e de mineração. 2.ed. Viçosa, MG: Aprenda Fácil, 2009. 270p.

MODESTO, P. T.; SCABORA, M. H.; COLODRO, G. MALTONI, K. L.; CASSIOLATO, A. M. R. Alterações em algumas propriedades de um Latossolo degradado com uso de lodo de esgoto e resíduos orgânicos. Revista Brasileira de Ciência do Solo, v.33, n.5, p.1489-1498, 2009.

MORAES, L.A.C.; GASPAROTTO, L.; MOREIRA, A. Fungos micorrízicos arbusculares em seringueira em Latossolo Amarelo distrófico da Amazônia Ocidental. Revista Árvore, v.34, n.3, p.389-397, 2010.

Revista Árvore, Viçosa-MG, v.40, n.2, p.245-254, 2016
RAMOS, P.S.; FARIA, J. Biomassa Florestal, oportunidade e valor. Revista da Associação Nacional de Empresas Florestais, Agrícolas e do Ambiente, n.11, p.23-26, 2011.

SANTOS, R.B.; SOUZA, T.S.; LACERDA JUNIOR, V.; CASTRO, E.V.R. Síntese e estudo do biodiesel do óleo da cutieira (Joannesia princeps). Vitória: 2009. Disponível em: http:// pt.scribd.com/doc/22582236/Analise-de-Biodiesel. Acesso em: 28 out. 2013.

SCREMIN-DIAS, E.; KALIFE, C.; MENEGUCCI, Z.R.H.; SOUZA, P.R. Produção de mudas de espécies florestais nativas. Campo Grande: Universidade Federal do Mato Grosso do Sul, 2006. 59p. (Série Rede de Sementes do Pantanal).

SILVA, A.G. A viabilidade da utilização de compostos orgânicos em solos agricultáveis. 2008. $25 \mathrm{f}$. Trabalho de Conclusão de Curso (Graduação em Tecnologia de Cafeicultura) - Escola Agrotécnica Federal de Muzambinho, Muzambinho, 2008.

SIQUEIRA, J.O.; LAMBAIS, M.R.; STURMER, S.L. Fungos micorrízicos arbusculares: características, associação simbiótica e aplicação na agricultura. Revista Biotecnologia Ciência \& Desenvolvimento, n.25, p.12-21, 2002.

SOUZA, N.H.; MARCHETTI, M.E.; CARNEVALI, T.O.; RAMOS, D.D.; SCALON, S.P.Q.; SILVA, E.F. Estudo nutricional da canafístula (ii): eficiência nutricional em função da adubação com nitrogênio e fósforo. Revista Árvore, v.36, n.5, p.803-812, 2012.

TAVARES, S.R.L.; MELO, A.S.; ANDRADE, A.G; ROSSI, C.Q.; CAPECHE, C.L.; BALEIRO, F.C.; DONAGEMMA, G.K.; CHAER, G.M.; POLIDORO, J.C.; MACEDO, J.R.; PRADO, R.B.; FERRAZ, R.P.D.; PIMENTA, T.S. Curso de Recuperação de Áreas Degradadas: a visão da ciência do solo no contexto do diagnóstico, manejo, indicadores de monitoramento e estratégias de recuperação. Rio de Janeiro: Embrapa Solos, 2008. 228p. (Documentos, 103)

VIANA, V.M.; PINHEIRO, L.A.F.V. Conservação da biodiversidade em fragmentos florestais. Série Técnica IPEF, v.12, n.32, p.25-42, 1998. 